\title{
Redesign and Analysis of Logo in Campus Publishing Business as Corporate Identity
}

\author{
Vella Nabillah ${ }^{1}$, Mayang Marshita ${ }^{2}$ \\ * \\ Informatics Engineering, Batam State Polytechnic \\ Multimedia and Network Engineering, Batam State Polytechnic \\ vella_nabillah@gmial.com ${ }^{1}$, mayangm1660@gmail.com ${ }^{2}$
}

\begin{tabular}{l}
\hline Article Info \\
\hline Article history: \\
Received Jun 12th, 2021 \\
Revised Jun 20th, 2021 \\
Accepted Jul 26th, 2021 \\
\hline
\end{tabular}

\section{Keyword:}

\section{Polibatam Press}

visual identity

the logo.

\begin{abstract}
Polibatam Press already has a visual identity in the form of a logo, but that identity does not yet describe the identity of the company itself. Therefore, the company needs a corporate identity logo that describe the identity and easy to be remembered. The logo design process was designed using the stages structure in making of the logo. There are seven steps In designing a logo in accordance with the wishes of the client. The data analysis technique used in the testing stage of this study was a qualitative research method. Sample tesing on this method is using purposive sampling technique. This testing model is used to get respondents' perception of a topic according to the needs of researchers. The final results of this research and testing are a conclusion and the results of the review, so that the visual identity displayed will make it easier for the society to recognize Polibatam Press.
\end{abstract}

\section{INTRODUCTION}

PolibatamPress is a publication established by BatamState Polytechnic. The purpose of the establishment of PolibatamPress is, to meet the needs of publication of scientific work and publishing textbooks. Polibatam Press is not only engaged in publishing, but PolibatamPress is engaged in advertising. Polibatam Press has produced many products, one of which is a book with ISBNs, flayers, brochures, $\mathrm{x}$-banners, certificates, and business cards. The target market is the internal campus of the Batam State Polytechnic and universities in Batam.

PolibatamPress already has a visual identity in the formof a logo, but the PolibatamPress logo still does not have an identity that can describe its identity. So far people and clients know the existence of Polibatam Press only through word of mouth. Therefore, the company needs promotional media to introduce Polibatam Press. To be able to introduce and describe the identity of Polibatam Press requires a logo and corporate identity that is easily recognized by the public. The logo that has been designed will be applied to every corporate identity that displays corporate identity such as, administrative tools (stationary), promotional media (billboards, banners, banners, brochures), merchandise (mugs, $\mathrm{t}$-shirts, stickers, calendars, paper bags, notebooks, booklet).

The logo designing process is designed using the stages structure in making the logo. In making a logo there are five steps to making a logo that will be done by researchers in designing the visual identity desired by the client. At the testing stage of this study, the data analysis technique used was qualitative analysis. Testing samples on this model using the snowball technique. This testing model is used to get respondents' perceptions 
of a topic in accordance with the needs of researchers, the final result of this testing model in the form of a conclusion. Fromthe problems above, the writer raised the FinalProject with the title Redesign and Analysis of the Logo in the Campus Publishing Business as Corporate Identity.

\section{THEORY BASIS}

\subsection{Previous Research on the Logo as Corporate Identity}

This study discusses the logo as the Corporate Identity of a company that was carried out by previous researchers. Previous research makes a reference for writers in writing reports that observe the logo as the Corporate Identity of a company. This literature review discusses the concepts used in reviewing the research conducted.

\subsection{The logo}

Logo is an abbreviation of the word from Logotype which comes from the Greek language, logos. The term Logotype first appeared in 1810-1840. Logotype has the meaning of writing a name specificaly designed using lettering techniques or using certain types of letters. With the time Logotype changed to Logo, the termlogo appeared in 1937. Until now the termlogo is very popular compared to Logotype. The logo uses elements in the formof text, images, illustrations and logograms. Logogramis a writing symbol that represents a word / meaning. General criteria in making / designing a logo are that the shape, color and size must be simple and flexible. The main criteria for the iyalah logo (Rustan, 2009):

a) Is unique. A logo must have the characteristics of each and different fromother logos. The logo must also raise the image of the entity.

b) A logo must be flexible as well as durable, and accommodate the dynamics experienced by its enttitas

In designing a logo there are several steps that must be done to produce a logo design that has quality. The following are the stages that a design must consider in making a logo (Rustan, 2009):

\section{1) Research \& Analysis}

At this stage the thing to do is look for the facts of the entity. If the entity is a company, then the research will be in the form of a corporate structure, corporate identity, vision and mission, target market, and purpose in making a logo. In conducting research, an analysis is needed so that the datataken is more directed. This whole analysis will be summarized as a conclusion.

\section{2) Thumbnails}

Based on the results of research and analysis conducted, then making thumbnails in the formof visual brain storming or ways of developing ideas through visuals, such as rough sketches of pencils or pens done manually. It is not recommended to make computer stages at this stage of thumbnails.

\section{3) Computer}

After getting the visual results then transferred to the computer. The visual results are scanned and redrawn using drawing software. As for what is included drawing software is vector-based software such as Adobe Illustrator or CoralDraw. In making logos it is not recommended to design directly with a computer, it must go through the stages of thumbnails. Stages back and forth between computers to thumbnails and backto the thumbnails stage. This results in the logo not being optimal.

\section{4) Review}

After all the steps are carried out, several kinds of logos will be formed to be shown to the client to choose from. Stages of reviewing are not only done once, fromseveral logos that have been submitted the logo will be narrowed to 3 or up to 2 designs. This is done back and forth between the client and designer evaluation. Next, the finishing logo is done to make it more mature and suitable for publication. 


\section{5) Trademark Registration}

The completed logo is registered with the Directorate General of Intellectual Property Rights (Dirjen HAKI). The aim is to get the protection of the right from unauthorized use by other parties.

\section{6) Identity System}

At the stage of the identity system, the designer determines other attributes such as derivative logos, color systems, typographic systems, and the system of applying logos to various media.

\section{7) Production}

The next stage of the predetermined identity systemwill be applied in various media that already exist and are produced using a registered identity.

\subsection{Visual Identity (Corporate Identity).}

Visual identity is commonly called Corporate Identity. Loaded in a journal(Atsar, 2014)that in the opinion of Wheeler (2003), "Visual identity is a brand that triggers the perception and association of that brand. The basic recognition processes of a logo include the shape, color and overall content. "

Visual identity is a visual formand expression of the image and identity of a company. Visual identity displays a symbol that reflects the image to be created(Fachroza, I., 2015). Therefore it can be concluded that visual identity is an identity of a company that has a philosophy fromthe history of the company, visual identity in the form of an image that distinguishes it fromother companies. A visual identity said to be effective must have several characters in a journal (Danton Sihombing, 2001),namely:

1) Simple symbolism

Simplicity is the basis of a good combination of brand identity. The simpler the symbol is made, the clearer the message is delivered and hits people who see the symbol.

2) Has a strong visual trigger

An effective symbol is very influential on a product, a symbol must trigger a response to a product or company. For example, when we want to buy instant noodles, most people will remember even buying the Indomie brand directly.

3) Corporate identity must be memorable and impressive

Corporateidentityhas two properties, namely proposing and reminding. If consumers want to buy an item, consumers will remember the name of a company, it is called by proposing. If consumers come back and buy the same product, the manufacturer will be contacted by the company, so this is called a reminder.

Loaded in her journal (Maymun \& Swasty, 2018)according to Hasket, "Visual identity is also related to visual communication, because it is a simplified form of complex concepts and ideas that each person or company has." Visual communication is the process of transforming ideas and information that formvisuals, this communication is usually combined with graphic design in creating a media that can attract the attention of the audience(Apriyani, Prasetya, \& Muslim, 2004). One example of a combination of graphic design with visual communication is contained in a logo, because the logo contains elements in graphic design. The elements contained include shapes, textures, lines, spaces, and colors. In graphic design also applies the basic principles of visual design such as, Balance (Rhythm), Rhythm, Pressure (Emphasis), Proportion and Unity.

\subsection{Qualitative Research Methods}

Qualitative research is a study based on the philosophy of postpositivism, used to examine the natural conditions of objects where researchers are key instruments and data collection techniques are carried out by triangulation (combined), data analysis is inductive and the results of qualitative research emphasize more on the meaning of generalization. Qualitative research does not use population, the termpopulation was replaced by Spedley with the name "Social Situation" or social situation consisting of three elements namely: place, actor, and activity. The sample in this qualitative study was not named respondents but resource persons, participants or informants. Qualitative research samples are also called theoretical samples, because the 
purpose of this study is to produce theories.

\subsection{Research subject}

In determining the subject, qualitative research often uses purposive sampling and snowball sampling techniques. Purposive sampling technique is a technique for taking data sources by making certain considerations, such as determining the subject that is considered most knowledgeable about the problemthat is happening, or the subject that makes it easy for researchers to explore the object / social situation under study. Snowball sampling is the initial technique for taking data sources by taking a smallnumber of samples, but over time the sample becomes large, this is donebecause of the few data sources that do not find satisfactory results so looking for samples that are more accurate and complete.

\section{Data collection}

Qualitative research collecting data is done in natural conditions, researchers will conduct in -depth observations, interview and conduct documentation. Catherine Marshall and Gretchen Rossman said that (Sugiyono, 2017: 225) "Qualitative research collects data using interview, observation and documentation techniques."

\section{Interview}

According to Susan Stainback (Sugiyono, 2017: 232) by conducting interviews the researcher will find out more deeply about participants in interpreting situations and phenomena that occur, where this can not be found through observation. So it often happens when conducting qualitative research interviews combined with participatory observation. There are various types of interviews raised by Esterberg (Sugiyono, 2017:233) namely, Structured Interviews, Semi-Structured Interviews and Unstructured Interviews. When conducting interviews, researchers use notebooks to record the results of interviews, tape recorders to record conversations at the time of the interview, and cameras to document the atmosphere at the time of the interview. After conducting interviews the researchers recorded the results of the interview.

\section{Observation}

According to Sanafiah Faisal (Sugiyono, 2017: 226) observations are divided into three types namely, participatory observation, frank and vague observation and unstructured observation. This participatory observation involves the researcher taking part in the daily activities carried out by the data source and being involved in the work of the data source. In a company or government organization researchers can act as employees so that researchers can conduct and observe the environment around the company to collect data. These participatory observations are grouped into four parts, namely:

- Passive participation: the researcher comes to the place of the activity of the person being observed, but is not involved in the activity.

- Moderate participation: researchers can participate in several activities aimed at collecting data, but not all activities of researchers can participate.

- Active participation: the researcherdoes what the resourceperson does, but it is not yet complete.

- Complete participation: the researcher is fully involved in what the resource person does so the atmosphere is natural, the researcher does not look like he is conducting a research so that the researcher fully collects data.

3. Documentation

The document is a record of events that have already passed. Documents can be in the form of text, pictures and photos. Documents in the formof drawings include stories, biographies, regulations and policies. Documentation in the formof drawings includes photographs, vivid images, and sketches. Documentation of works in the form of sculptures, films, pictures and others.

\section{Data analysis}

In qualitative data analysis, Bogdan stated (Sugiyono, 2017: 244) that data analysis is the processof systematically searching and compiling data obtained frominterviews, field notes, and other materials making it easier to understand. Data analysis is done by organizing data, describing it into units, synthesizing, arranging 
into patterns, choosing what is important and making conclusions that can be shared with others. The process in data analysis is divided into three parts, namely, analysis before the field, data analysis in the field of Miles and Huberman models, data analysis during the field of Spradley Model.

\section{Data validation}

Qualitative research conducts validation using valid and reliable instruments and is carried out with a sample that is close to the number of social situations and the collection of correct data analysis. In the qualitative research that is tested is the data. According to Susan Stainback (Sugiyono, 2017: 268) qualitative research is more on the aspect of validity. The discovery is valid if there are no differences reported by researchers with what actually happened to the object under study. The state of reality of the data in qualitative research is not singular but plural and changing so that nothing is consistent. So the validity test of data in qualitative researchincludes the test of reliability, transferability test, dependability test and confirmability test.

\section{ANALYSIS AND DESIGN}

In this stage, the logo design process was designed using the structure of the stages of designing the logo taken from the Rustan bookin 2009, namely research \& analysis, thumbnails, computers, reviews, trademark registration, production and production systems (Rustan, 2009). Phase 1 will be described in the analysis and design chapter. At the stage of analyzing an identity, this study uses qualitative research methods that aimto find and arrange facts so that the resulting identity reflects that of the company. While Steps 2 to 7 will be described in the results and discussion chapter. The following is an overview of the structure in designing a logo which is explained in the image below.

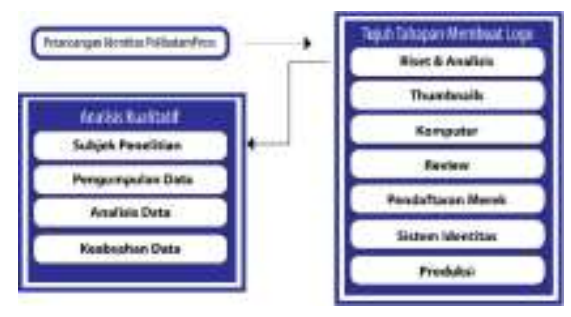

Figure 1. Stages of the process of designing visual identity

\subsection{Research andAnalysis}

At this stage the research and analysis is carried out by searching for data related to Polibatam Press and interviewing Polibatam Press to discuss the type of company, company targets, vision and mission, company competitors. As well as interviewing several employees / members, customers, and writers who have published textbooks and take some related documentation about Polibatam Press.

\subsubsection{Polibatam Press}

In 2017, to support the higher education of the tertiary institutions, it is necessary to publicize the intellectual assets of the higher education institutions to the public so that the Batam State Polytechnic has the initiative to establish publications to meet the needs of publication of scientific works and the publication of textbooks in the polytechnic environment. Then on October 16, 2017, with the issuance of the Decree of the director of the Batam State Polytechnic number 909/ K / PL29 / X / 2017 the publisher was officially given the name PolibatamPress.

In establishing a college, Batam State Polytechnic has an identity in the form of a logo. The logo is an identification for the BatamState Polytechnic, with the existence of this identity the tertiary institution canbe known by the surrounding community. Polibatam Press also has an identity in the form of a logo.

Under the auspices of the BatamState Polytechnic, PolibatamPress focuses on book publishing services, book sales and book publishing in the form of e-books, not only that Polibatam Press also opens printing services such as flayer printing, brochures, booklets and others. 


\subsubsection{Polibatam Press Vision and Mission}

\section{Vision}

"Become a Professional, Characteristic, Innovative Publishing and Printing Company that can provide benefits, meet the needs of publication of scientific papers and textbooks in the polytechnic environment and be able to open profitable employment opportunities."

\section{Mission}

1. Building a Publishing and Printing Business that is able to provide service and satisfaction for customers.

2. Creating an innovation for the creation of added value in a product that can be profitable.

3. meet the needs of publication of scientific papers and textbooks in the polytechnic environment.

4. Presenting professional jobs with productive work.

\subsubsection{Polibatam Press Organizational Structure}

Polibatam Press stands under the responsibility of the director of Polibatamand is led by a chairperson. At present a lecturer has been appointed to be chairman. To run PolibatamPress operations, it is led by the head of operations, namely Polibatam lecturers, assisted by two Account Executive staff, responsible for administration, ISBN and other supporting documents, and two Financial Accounting departments responsible for recording receipts, cash disbursements, taxpayments, salaries. and preparation of financial statements. The editor is one person and is responsible for editing the contents of the book, the design part is two people, this part is responsible for the design and layout of the product to be printed. The production department is as much as one person who is responsible for the printing process up to product quality assurance.

\subsubsection{Corporate identity and product design}

In conducting research on Polibatam Press there are several designs that have been applied to show the corporate identity of a company in addition to the logo and company name. The design is also applied to administrative tools (stationary), social media and products produced by Polibatam Press such as books and souvenirs from KIT seminars.

\subsubsection{Stages of Analysis}

In conducting the analysis, a qualitative method was used to find deeper information about the publication of Polibatam Press. Testing the sample on this method using purposive sampling technique. The stages of qualitative methods consist of research subjects, data collection, data analysis and data validation.

1) Research subject

In determining the subject, a purposive sampling technique was used in finding sources of information regarding the publication of Polibatam Press. In this study the subject was divided into 2 namely, internal and external subjects. Internal subjects are people who are directly involved in establishing PolibatamPress, such as company leaders and employees. While the external subject is Polibatam Press consumers who are stil one environment in the Batam State Polytechnic. The consumers who are the subjects of the research are several authors who publish textbooks on Polibatam Press.

2) Data collection

Furthermore, data collection is done by structured interview techniques, participant observation that is complete in nature and documentation.

- $\quad$ Interview

Before conducting an interview there are a number of things that must be prepared such as, questions that will be asked to subjects that have been determined, sound recording devices and materials needed at the time 
of the interview.

\section{- Observation}

The next step uses the complete Participatory Observation technique. At this stage the observations were made directly on the company Polibatam Press. The things that were observed by researchers were:

a. Polibatam Press Room

b. People involved in Polibatam Press other than researchers

c. The objects in Polibatam Press

d. The series of activities carried out by people at Polibatam Press

3) Data analysis

In the stages of data analysis using the Miles and Huberman model techniques (Sugiyono, 2017). Data analysis is divided into 3 steps:

\section{- $\quad$ Data Reduction}

This step is the recording of data obtained carefully and in detail. After that the data will be focused on things that are important. The things that are focused are taken froma combination of visual aspects of internal and external subjects during the interview, namely: The existence of the company, the company's target, the type of company, the shape of the company's identity, the color of the company's identity and the font / writing of the company's identity.

$$
\text { - Display Data }
$$

After the interview data has been reduced, the data will be displayed in tabular form, so that the interview results obtained are easily understood.

\section{- $\quad$ Conclusion drawing}

The conclusion fromthe results of data analysis conducted is PolibatamPress is a publication that stillstands under the auspices of the BatamState Polytechnic. PolibatamPress is engaged in publishing and at the same time provides printing services. As for the target of this company is internal fromBatam State Polytechnic such as lecturers, campus community and students who want to have an interest in writing books, PolibatamPress also targets the general public who want to publish books. The formof PolibatamPress's identity has explained the form of the company seen in the book object, but the form of identity is still not in accordance with the vision and mission, the form of identity has clearly illustrated so that the interpretation and description of PolibatamPress are not yet visible. The color on the logo is identical to the color on the identity of the Batam State Polytechnic. The writing / font used is clear and simple.

\section{RESULTS AND DISCUSSION}

In this chapter the results of the implementation of the design are described based on the stages of making logos, namely thumbnails, computers, reviews, trademark registrants, and identity systems.

\subsection{Thumbnails}

From the research and analysis collected then processed into rough sketches in the form of visuals. In the process of making visuals, sketches are drawn manually using a pencil. The sketching process can be seen in Figure 4.1.

\subsection{Computer}

After getting visual results fromthe thumbnails stage, the logo is then designed using a drawing software application. The application used is Adobe Illustrator CS6. The process of this activity is illustrated in Figure 4.2 and Figure 4.3. 


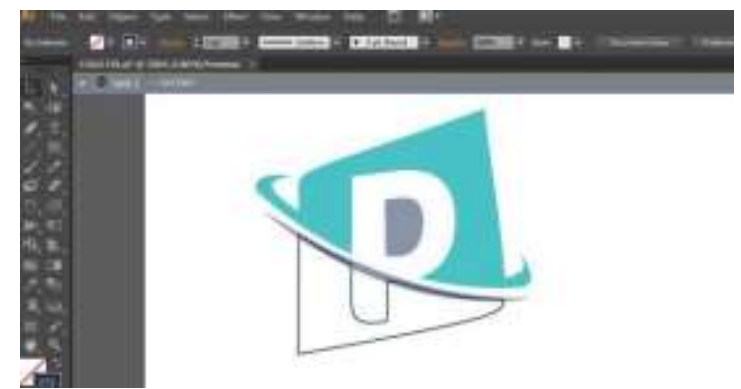

Figure 2. Design Process Using Adobe Illustrator CS6.

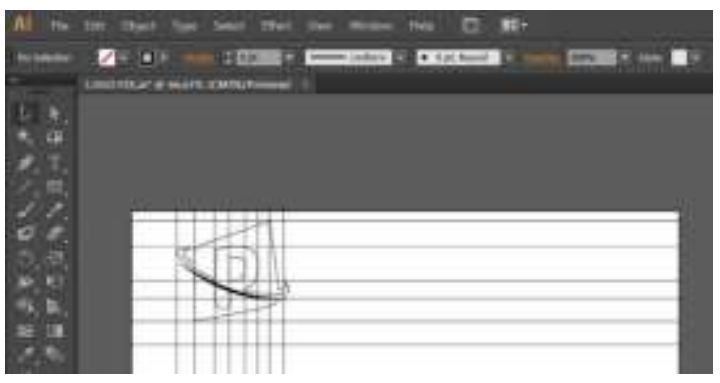

Figure 3 The Process of Coloring the Logo

At this stage, several designs will be reviewed by the owner of the Polibatam Press company. The results of the design can be seen in figures 4.4 and 4.5

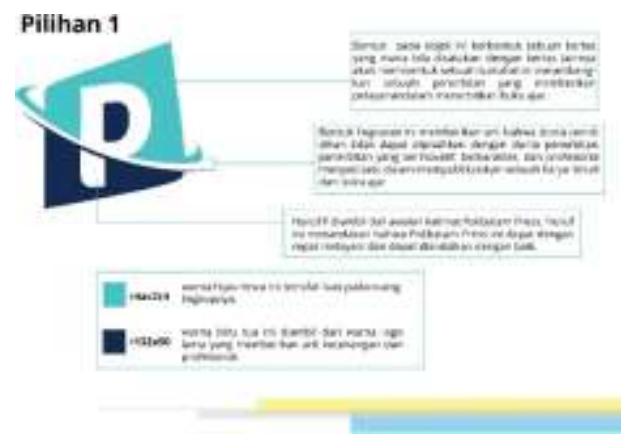

Figure 4 First Logo Design Results

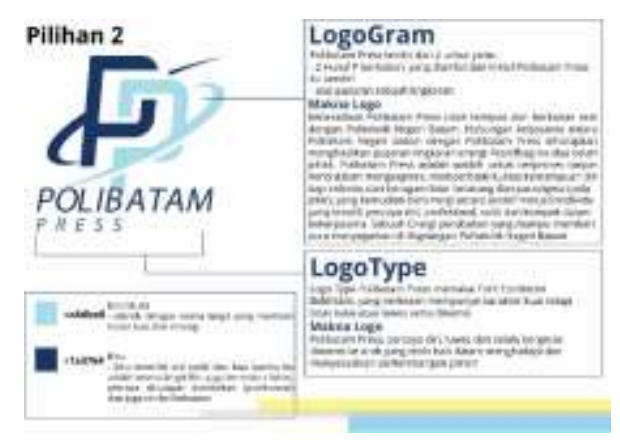

Figure 5 Second Logo Design Results

\subsection{Review}

At this stage, the company owner reviews a number of logo designs that have been produced. The review process is carried out online. At the time of the logo review, there were a number of things that were observed by the owner of the company starting fromthe meaning of the logo, placement on the stationary of the company and the products produced by PolibatamPress. The results of the review on the logo are in the second option in the form of the symbol of the company name. 


\subsection{Trademark Registration}

The process of trademark registration on the Polibatam Press identity is carried out in two s tages. The first stage is registering the brand name and the second stage is registering the logo. In 2019 the brand name registration has been carried out and already obtained intellectual property rights (IPR). Whereas the identity of the company logo is at the stage of the submission process to the directorate general of intellectual property rights (IPR).

\subsection{Identity System}

The meaning of the logo that has been determined by the owner of the company Polibatam Press is explained in table 1:

Table 1. Identity System

\begin{tabular}{|c|c|}
\hline Picture & The meaning of pictures \\
\hline & $\begin{array}{l}\text { Shape of Logogram Meanings:PolibatamPress logogramconsists of } 2 \text { elements viz } \\
\text { - } 2 \text { letters P are related, taken fromthe initialPolibatamPress itself } \\
\text { - the vortexflow of a circle, the existence of Polibatam Press is inseparable and } \\
\text { closely related to the Batam State Polytechnic. The cooperative relationship } \\
\text { between the BatamState Polytechnic andPolibatamPress is expected to produce a } \\
\text { positive energy cycle vortexfor both parties }\end{array}$ \\
\hline $\begin{array}{l}\text { PULIBATAM } \\
\text { PRES }\end{array}$ & $\begin{array}{l}\text { Form of the Meaning of Logotype:Polibatam Press, confident, flexible and always } \\
\text { moves dynamically towards a better way to face and adjust the development } \\
\text { of the times. }\end{array}$ \\
\hline +asdbes & $\begin{array}{l}\text { The Meaning of Color in the Logo: Light blue has identical color to the sky } \\
\text { which gives a broad and calmimpression. } \\
\text { Dark blue has a stable and broad meaning because it is the color of the sea. Blue also } \\
\text { means focus, confidence, reliable (professional) and also a symbol of strength }\end{array}$ \\
\hline 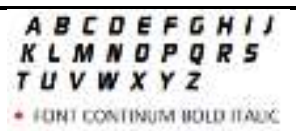 & $\begin{array}{l}\text { The Meaning of Fonts in the Logo: Bold Italic's Continumfont, which impresses, has } \\
\text { a strong character but is not rigid or flexible and dynamic }\end{array}$ \\
\hline
\end{tabular}

\subsection{Product}

The application of the logo is carried out on administrative tools (stationary) and Polibatam Press products in the formof books, MUGs, and seminar kit packages. The results of the application can be seen in Figure 4.6 and Figure 4.7.
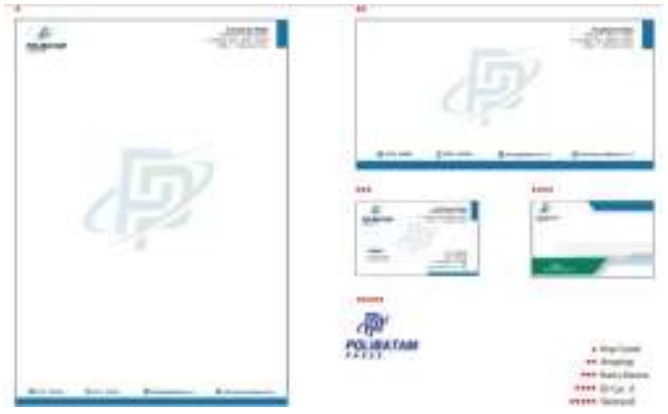

Figure 6. Results of Applying Logo on Administration Tools (Stationary) 


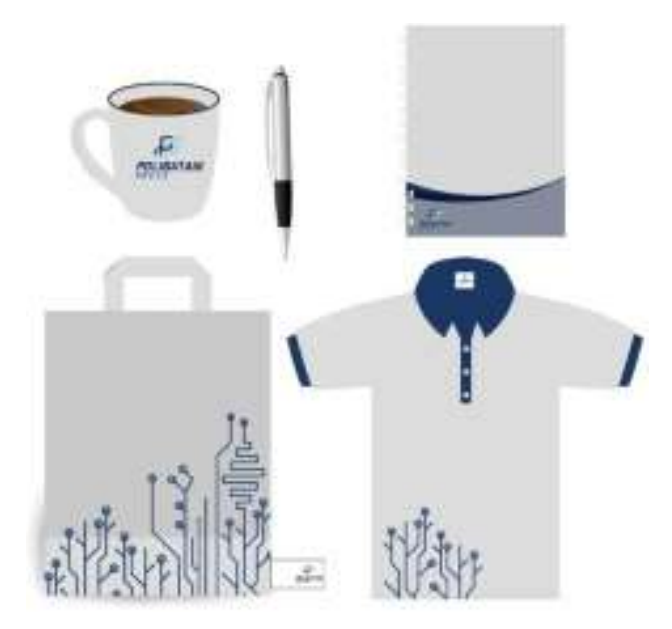

Figure 7. Results of Applying Logo on Polibatam Press Products

\section{CONCLUSION}

The conclusions that can be drawn fromthe results of research and fromthe foundations of theory thathave been compiled are as follows:

1. Polibatam Press is a publication established by Batam State Polytechnic. The purpose of the establishment of Polibatam Press is, to meet the needs of publication of scientific work and publishing textbooks. PolibatamPress focuses on book publishing services, booksales and bookpublishing in the form of e-books, not only that Polibatam Press also opens printing services such as flayer printing, brochures, booklets and others.

2. Polibatam Press requires a logo and corporate identity that is easily recognized by the public. The logo designing process is designed using the stages structure in making the logo. In making a logo there are seven steps to making a logo that will be carried out by researchers in designing the visual identity desired by the company.

3. 3. Giving and adding designelements and illustrations to promotional mediain the formof print media is very helpfuland effective, because it can create a sense of community curiosity about the superiority of Polibatam Press from other printing presses through existing displays.

\section{REFERENCES}

Ad”R, G., Adr", V., \& Pascu, N. E. (2012). Logo Design And The Corporate Identity. Procedia - Social And Behavioral Sciences, 51, 650-654. Https://Doi.Org/10.1016/J.Sbspro.2012.08.218

Adimarta, P., \& Apriyani, M. E. (2014). Redesign Corporate Identity Pada PT . Sentral Mega Konsultan . 6(1), 41-45. Agusta, I. (2003). Teknik Pengumpulan dan Analisis Data Kualitatif, Litbang Pertanian,

Bogor.

Alam, P. K. (2016). Perancangan Ulang taIdentitas Visual Pt. Pintu Nusantara Tour Event \& Travel Planner Serta Penerapannya Pada Media Promosi Proyek Studi,Universitas Negeri Semarang .

Apriyani, M. E., Prasetya, H. Y., \& Muslim, A. (2004). Perancangan Identitas Visual PT . Indika Kelola Gemilang Sebagai Media Promosi.

Astriyani, E., Lukmana, A., \& Irawan, A. (2016). Media Video Company Profile Sebagai Sarana Informasi Dan Promosi Di PT.Surya Toto Indonesia Tbk. Kabupaten Tangerang. Cices Journal, 2(2), 204-215.

Atsar, F. (2014). Persepsi Dan Citra Identitas Visual Logo Bank Mandiri. Jurnal Itenas Rekarupa, JAMN Vol. 5, No. 2, July 2021 
2(1), 10-19.

Fermana, (2019). (2019). Redesign Logo Winnie Fruit Padang. Duke Law Journal, 1(1), 1-13.Https://Doi.Org/10.1017/Cbo9781107415324.004

Hananto, B. A. (2019). Perancangan Identitas Visual Dan Desain Kemasan Produk Makanan (Studi Kasus: Fibble). Gestalt, 1(1), 77-94. Https://Doi.Org/10.33005/Gestalt.V1i1.21

Kuncoro, W. A. (2018). Analisis Knowledge Sharing Menggunakan Metode Focus Group

Discussion(FGD). Behaviour And Information Technology, 04(11), 2442-7942.

Https://Doi.Org/10.1080/0144929X.2012.745277

Lumombo, L., (2017) Logo Pembelajaran Politeknik Negeri Batam, Batam, Modul Kuliah Politeknik Negeri Batam

Maymun, A. Z., \& Swasty, W. (2018). Identitas Visual Dan Penerapannya Pada Signage Untuk Kawasan Wisata Edukasi.

Serat Rupa Journal Of Design, 2(1), 01. Https://Doi.Org/10.28932/Srjd.V2i1.473

Mujianto, Z. (2013). Kajian visual perubahan logo perusahaan umum(Perum) perhutanan, Universitas negeri yogyakrta, Yogyakarta

Rustan., (2009). Mendesain Logo. Jakarta: PT Gramedia Pustaka Utama.

Saladin, D., \& Oesman, Y. M. (2003). Intisari Pemasaran Dan Unsur-Unsur Pemasaran. Cetakan Ketiga, Bandung: Linda Karya.

Sayatman., \& Darmawati, N. O. (2017). Pengembangan Metode Desain Logo dan Sistem Grafis untuk Mendukung Pembelajaran Desain Komunikasi Visual. Institut Teknologi Sepuluh Nopember,Junal desain, Vol.16 (2), 
